\title{
成人後期の主観的幸福感に対する 日常生活活動能力および個人背景要因の影響
}

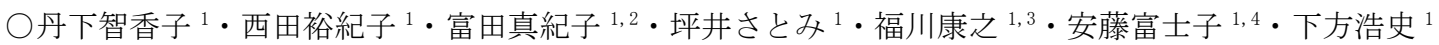
$\left({ }^{1}\right.$ (独) 国立長寿医療研究センター予防開発部・2名古屋大学大学院教育発達科学研究科・

${ }^{3}$ 早稲田大学文学学術院・ 4 愛知淑徳大学健康医療科学部)

キーワード : 主観的幸福感 日常生活活動能力 成人後期

The effect of activities of daily living and personal background factors to subjective well-being among Japanese elderly people Chikako TANGE ${ }^{1}$, Yukiko NISHITA ${ }^{1}$, Makiko TOMIDA ${ }^{1,2}$, Satomi TSUBOI ${ }^{1}$, Yasuyuki FUKUKAWA ${ }^{1,3}$, Fujiko ANDO ${ }^{1,4}$, and Hiroshi SHIMOKATA ${ }^{1}$

( ${ }^{1}$ Dept. for Development of Preventive Medicine, NCGG, ${ }^{2}$ Nagoya Univ., ${ }^{3}$ Waseda Univ., ${ }^{4}$ Aichi Shukutoku Univ.) Key Words: Subjective well-being, ADL, elderly

\section{【目的】}

一般的に加齢とともに日常生活活動能力は低下寸るが、そ の活動能力の低下が主観的幸福感の低下につながる可能性が 示唆されている (丹下他, 2011)。本研究は個人背景要因の違 いにより、日常生活活動能力の主観的幸福感に対する影響に 差異が示されるか否かを検討することを目的とした。

\section{【方法】}

分析対象「国立長寿医療研究センター・老化に関する長期縦 断疫学研究 (NILS-LSA)」の第 4 次調査 (2004.6-2006. 7) から第 6 次調查 (2008.7-2010.7) に参加した地域住民のうち、60 歳以 上の 1655 名(男性 822 名、女性 833 名、延べ 3764 名)を分析 対象とした (調査参加時年齢 60-89 歳、平均 70.9 1 6.9 歳)。

尺度 第 4 次-第 6 次調査において、以下の尺度を含む自記式 調查票を実施した。(1)生活満足度尺度 K (古谷野, 1996 : LSI-K) : 主観的幸福感の肯定的側面。(2) Center for Epidemiologic Studies Depression Scale(Radloff，1977；島 他，1985：CES-D)：主観的幸福感の否定的側面。(3)老研式活 動能力指標（古谷野他，1987：ADL）：「手段的自立」、「知的能 動性」、社会的役割」の 3 側面から総合的な日常生活活動能力 を查定。(4)個人背景要因 : 経済状態満足度、主観的健康感、 婚姻状況。

解析 $\mathrm{ADL}$ 得点の 11 点以下を低群、12 点以上を高群と群わけ した。個人背景要因については、経済状態満足度は 5 段階評 定から「不満/どちらでもない/満足」に、主観的健康感は 5 段階評定から「悪い/普通/良い」に、婚姻状況は回答時点で の「配偶者の有/無」にそれぞれまとめた。そして男女別に、 LSI-K および CES-D を従属変数とした混合効果モデルによる 解析を行った。説明変数として各個人背景要因および ADL 群 の主効果および各個人背景要因と ADL 群の 1 次の交互作用項 を、調整変数として出生年と測定時期を、変量効果として切 片を投入した。

\section{【結果】}

解析の結果（表 1)、ADL は全ての場合に有意な主効果を示 し、ADL 高群の方が低群よりも LSI-K は高く、CES-D は低かっ た。経済状態満足度および主観的健康感に関しては、男女と も LSI-K、CES-D に有意な主 効果を示し、これらに対す る評価がポジティブである 場合に LSI-K は高く、CES-D が低いことが下位検定から 示唆された。配偶者の有無 に関しては、男性のみに有 意な主効果が示され、配偶 者がいない場合に LSI-K が 低く、CES-D が高いことが示 された。個人背景要因とADL

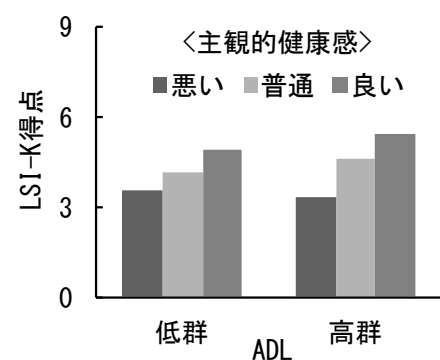

図1 女性 : ADL群別での主観的 健康感によるLSI-K得点

の交互作用に関しては、主観的健康感との交互作用が女性の LSI-K、および男性の CES-D に、経済状態満足度との交互作用 が女性の CES-D に示された（図 1-図 3)。すなわち、女性の $\mathrm{ADL}$ 低群と比較して高群では健康に対する評価の高さが LSI-K 得点により強くポジティブに作用していた。また、ADL 高群と比較して低群では、男性の主観的健康感および女性の 経済状態満足度の評価の低さが CES-D 得点により強くネガテ イブに作用していた。

\section{【考察】}

本研究の結果から、男女とも ADL が高い場合、および自分 の経済状態や健康に関してポジティブな評価をする場合に主 観的幸福感が高いことが示唆された。また、男性に関しての み配偶者がいることが高い主観的幸福感につながることが示 された。これらの結果は、日本人高齢者に関する先行研究の 知見と合致するものである。一方、研究の焦点であった ADL の高さと個人背景要因を掛け合わせた場合には、部分的に主 観的幸福感に対する有意な交互作用が示された。すなわち ADL が低下した場合には、健康や経済状況などの要因が主観的幸 福感に対して持つプラスの効果は押さえられ、マイナスの効 果はより大きくなる可能性が示唆されたといえよう。

なお、今回の解析においても、各種要因が直接的・間接的 に主観的幸福感に与える影響が、性別により異なることが示 唆された。今後、性差も踏まえつつ、さらに解析を進める必 要があるだろう。

表1 LSI-KおよびCES-Dの混合効果モデルによる解析結果（F値）

\begin{tabular}{|c|c|c|c|c|}
\hline \multirow[b]{2}{*}{ 固定効果 } & \multicolumn{2}{|c|}{ LSI-K } & \multicolumn{2}{|c|}{ CES-D } \\
\hline & 男性 & 女性 & 男性 & 女性 \\
\hline$\overline{\mathrm{ADL}}$ & $7.51^{* *}$ & $4.25^{*}$ & $18.25^{* * *}$ & $56.78^{* * *}$ \\
\hline 主観的健康感 & 44. $22^{* * *}$ & 49. $31^{* * *}$ & $54.00^{* * *}$ & 45. $35^{* * *}$ \\
\hline 配偶者の有無 & 4. $99 *$ & 0.31 & $17.73^{* * *}$ & 0.71 \\
\hline 経済状態満足度 & $57.42^{* * *}$ & $36.88^{* * *}$ & 15. $31^{* * *}$ & 14. $08^{* * *}$ \\
\hline 主観的健康感 $\times A D L$ & 0.13 & $4.04 *$ & 4. $02 *$ & 0.39 \\
\hline 配偶者の有無 $\times$ ADL & 0.09 & 0.85 & 1.97 & 1. 91 \\
\hline 経済状態満足度 $\times$ ADL & 0.21 & 0.61 & 0.31 & 4. $99^{* *}$ \\
\hline
\end{tabular}

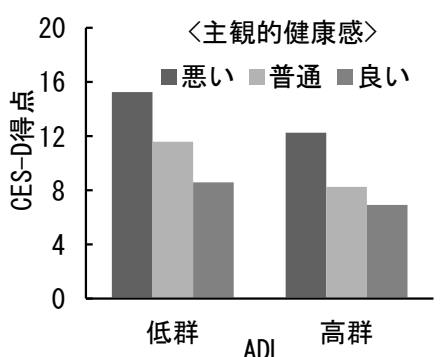

図2 男性 : ADL群別での主観的 健康感によるCES-D得点

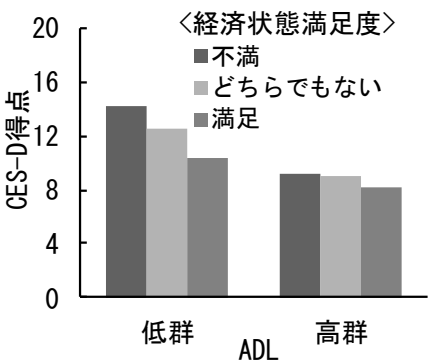

図3 女性: ADL群別での経済 状態満足度によるCES-D得点 